\title{
Some Features of the Fine Structure and Chemical Composition of Rhizobium trifolii
}

\author{
BY J. M. VINCENT, BEVERLEY HUMPHREY AND R. J. NORTH \\ Microbiology Laboratory, School of Agriculture and the Electron Microscope \\ Unit, University of Sydney, Australia.
}

(Received 9 March 1962)

\section{SUMMARY}

The conspicuous, large, high refractive index, sudanophilic granules of Rhizobium trifolii appeared to be aggregations of polymeric $\beta$-hydroxybutyric acid, probably closely associated with the cytoplasm. They became more conspicuous as the organism aged, provided that carbohydrate was in excess. A well-grown culture contained 40-50\% polymer, based on cell dry weight. Relatively large cytoplasmic granules $(50-80 \mathrm{~m} \mu)$ were a feature of this organism whether in fixed and sectioned cells or in material shadowed after mechanical disintegration.

Classical 'double' (? lipoprotein) membranes were demonstrated both for the cell wall and the cytoplasmic membrane. Carefully fixed and embedded material often showed an accumulation of material between the two double membranes, especially at one or both ends, without any evidence of gross damage in the sectioned organisms.

\section{INTRODUCTION}

Rhizobium trifolii consists of motile Gram-negative rods, approximately $2 \mu \times 1 \mu$, which characteristically stain unevenly with the usual basic dyes. Burdon (1946) noted that Rhizobium possessed more sudanophilic granules than most Gramnegative genera. Others (Forsyth, Hayward \& Roberts, 1958; Smithies, Gibbons \& Bayley, 1955) have reported rhizobium as one of many organisms that contain a polymer of $\beta$-hydroxybutyric acid. This polymer was first described in Bacillus megaterium by Lemoigne (1925), and was found by Képès \& Peaud-Lenoel (1952) to consist of $\beta$-hydroxybutyric acid molecules linked through the carboxyl and hydroxyl groups into chains of various lengths.

We were made particularly aware of this polymer in our attempts to prepare cell walls of rhizobium by usual procedures. In this we were frustrated by the large amounts of sticky material which formed as globules when the cells were disintegrated and which could not be separated from the walls by differential centrifugation. Dr M. J. Salton's suggestion that this material might be the polymer led to a modified procedure giving us a clean preparation and the means of analysing the walls of normal and abnormal calcium-deprived cells (Humphrey \& Vincent, 1962).

This paper reports some features of the rhizobial cell revealed by the electron microscope, and observations on the polymeric $\beta$-hydroxybutyric acid which so much affects the appearance of the organisms under the light microscope. 


\section{METHODS}

Organism. Rhizobium trifolii SU 297/31.

Cultural conditions. It was grown in a defined medium (Vincent, 1962) having a total concentration of divalent cation of $1 \mathrm{~mm}$. Cultures were aerated by shaking and grown for 3-4 days at $25^{\circ}$.

Light microscopy. Phase equipment was used for the examination of unstained cells. Otherwise normal staining methods were used, including the procedure of Burdon (1946) for Sudan Black B.

Electron microscopy. The organism was fixed with $2 \% \mathrm{KMnO}_{4}$ using $2 \%$ uranyl nitrate as a post-fixative (North, 1961) to obtain better definition of membranes, embedded in araldite, and sectioned and examined in the Siemens electron microscope. Shadowed preparations were by normal techniques.

\section{RESULTS}

\section{Structure}

Appearance under the light microscope. The larger cells of a well grown culture contained several conspicuous refractile granules, clearly seen under the phase microscope, which corresponded in position to areas which remained unstained with simple basic dyes, but which were strongly sudanophilic. In shorter, and presumably younger cells, on the other hand, the more refractile material was restricted to the ends in 'polar caps', but this material appeared to be different from that of the granules (see below). In cells of intermediate length there was a conspicuous central granule, generally in cells still having 'polar caps'. Table 1 summarizes the distribution of these three main conditions in relation to cell length. When the culture as a whole was younger $(16 \mathrm{hr}$.), the refractile granules were smaller and less frequent.

\section{Table 1. Relationship of cell structures to cell length}

The organism was grown in the defined medium containing $\mathrm{Ca}^{2+}$ for $85 \mathrm{hr}$. at $25^{\circ}$.

Distribution of cells according to length $(\mu)$

Cell condition

Without granules but with 'polar caps'

With central granule, generally with 'polar caps'

With multiple granules

\begin{tabular}{|c|c|c|c|c|c|}
\hline $0 \cdot 8-1 \cdot 3$ & $1 \cdot 4-1 \cdot 8$ & $1 \cdot 9-2 \cdot 4$ & $2 \cdot 5-3 \cdot 0$ & $3 \cdot 0$ & Total \\
\hline 17 & 5 & 1 & 0 & 0 & 23 \\
\hline 10 & 22 & 8 & 3 & 0 & 43 \\
\hline 0 & 6 & 14 & 11 & 3 & 34 \\
\hline
\end{tabular}

When the organism was mounted in media of higher refractive index (R.I.), it was found that the central and multiple granules had R.I. = 1.41, compared with about 1.38, the R.I. of the rest of the cell. Extraction with chloroform removed the most refractile granules, leaving areas having a lower R.I. than the rest of the cell and which could now be stained, though lightly, with methylene blue and other basic dyes. 'Polar caps' were not extracted by chloroform and were further distinguishable from the other granules in that formation of the latter was prevented when the carbon source was limiting.

The properties of the granules in situ (i.e. high R.I., ability to stain with Sudan 
Black, failure to stain with basic dyes, and solubility in chloroform) were compatible with those of polymeric $\beta$-hydroxybutyric acid. This substance was obtained in quantity from this organism (see below), and these facts, considered along with those of Lemoigne (1946) and Williamson \& Wilkinson (1958) for other bacteria, led to the conclusion that the high R.I. granules did, in fact, contain a large amount of the polymer. This probably constituted a food reserve formed under conditions of abundant carbon supply (Macrae \& Wilkinson, 1958; Doudoroff \& Stanier, 1959; Merrick \& Doudoroff, 1961).

Fine structure. Two sets of double membranes were observed in ultra-thin sections under the electron microscope (Pl. 1, figs. 1, 2). The outer, which we took to be the cell wall, had structure and dimensions in agreement with those described by Kellenberger \& Ryter (1958) for Escherichia coli. Two $30 \mathrm{~A}^{\circ}$ dark lines were separated by a $30 \AA$ clear space so that the whole could represent the classical lipoprotein double layer. Additionally the outer layers appeared to have associated with them granular, electron-dense material that gave the wall a rather more substantial appearance than the underlying cytoplasmic membrane.

The inner membrane was also clearly resolved in these preparations. It had the same over-all dimensions (about $80 \AA$ ) as what appeared to Kellenberger \& Ryter (1958) to be a single-layered structure in Escherichia coli but which was probably not resolved in their case. Beer (1960) recently reported a double-layered cytoplasmic membrane in Alcaligenes faecalis. The dimensions we observed for the cytoplasmic membrane were similar to the double-layered unit membrane of higher organisms (Robertson, 1955, 1958). We, like Beer (1960), often found a large area at one or both poles of the cell that separated the cell wall and the cytoplasmic membrane (Pl. 1, fig. 3). This might have represented shrinkage, but it was by no means empty of electron-dense material and both the cytoplasmic membrane and the cell wall enclosing the area appeared to be well organized and relatively undamaged. Its location and dimensions were, moreover, the same as the terminal areas of high R.I. ('polar caps') seen regularly in the living organism with phase illumination. It is possible that these areas were real structures and represented material excreted into the inter-membrane space from the cytoplasm, or synthesized at the outer surface of the cytoplasmic membrane.

The cytoplasm enclosed by the inner membrane contained many electron-dense and roughly spherical bodies, about $50-80 \mathrm{~m} \mu$ diam. (Pl. 1, fig. 2). In this respect the cytoplasm of rhizobium differed from the more finely granular cytoplasm of other bacteria. Similar spherical bodies were liberated from disrupted cells (Pl. 1, fig. 4) and a concentrated fraction of this material showed vigorous succinoxidase activity. The chemical nature of the granules has not yet been fully investigated. Because they appeared so electron-dense in permanganate-fixed preparations, and because of their enzymic activity, they were likely to contain a considerable amount of protein. On the other hand, they were also obvious with osmium tetroxide fixation.

\section{Composition}

Isolation and identification of polymeric $\beta$-hydroxybutyric acid. Washed freeze-dried cells were shaken with chloroform for $24 \mathrm{hr}$. at $25^{\circ}$ and separated from the liquid by filtration under pressure. When the chloroform was evaporated, this highly viscous solution left a thin 'plastic' film clinging to the glass surface. It was also refractile 
and sudanophilic, and dried in the polygons observed by Lemoigne, Sanchez \& Girard (1943). The chloroform solution, when poured into three volumes of ether, produced a white flocculent precipitate adhering in strings to the stirring rod. This material melted sharply at $179^{\circ}$, compared with $160-179^{\circ}$ as variously reported for this polymer. This value is probably dependent on the length of the polymer chain. It was soluble in phenol, pyridine and $\mathrm{N}-\mathrm{NaOH}$, but insoluble in ether, acetone and dilute mineral acids.

Heating the dry polymer in a tube caused it to melt and fume, and the plate-like crystals which condensed on the cold part of the tube had a melting point of $69^{\circ}$. These crystals decolorized $\mathrm{KMnO}_{4}$ (the test for unsaturation in the molecule) as would be expected of crotonic acid (m.p. $70^{\circ}$ ), the sublimation product of $\beta$-hydroxybutyric acid.

The polymer was saponified by $\mathrm{N}-\mathrm{NaOH}$ in $30 \mathrm{~min}$. at $100^{\circ}$ to give a 'soapy' solution. $\mathrm{Na}^{+}$was removed by Amberlite $120 \mathrm{R} \mathrm{H}^{+}$and the resulting solution used for chromatography by the method of Duncan \& Porteus (1953). The main spots of the chromatogram corresponded to the markers of authentic $\beta$-hydroxybutyric acid and crotonic acid. Hydrolysis of the polymer for $48 \mathrm{hr}$. in $6 \mathrm{~N}-\mathrm{HCl}$ at $100^{\circ}$ did not dissolve the material completely, but the soluble portion contained mainly $\beta$-hydroxybutyric acid. Amino-acids and sugars could not be detected in the hydrolysate.

\section{Table 2. Increase of poly $\beta$-hydroxy-butyric acid with age of culture}

$\begin{array}{cc}\begin{array}{c}\text { Age of culture } \\ \text { (hr.) }\end{array} & \begin{array}{c}\text { \% polymer in cell } \\ \text { dry wt. }\end{array} \\ 16 & 39 \\ 37 & 41 \\ 86 & 50\end{array}$

As the cells aged in the presence of sufficient carbohydrate and the refractile granules became more conspicuous, the percentage of polymer increased (Table 2). Cultures growing in limiting amounts of carbohydrate produced considerably less polymer and showed a decline in opacity with age, probably an indication of the polymer being utilized as a food reserve.

\section{DISCUSSION}

In our electron micrographs we seldom saw the conspicuous inclusions of polymer found by Schlegel, Gottschalk \& von Bartha (1961) in Hydrogenomonas. It may be that the polymer was completely or largely removed during our preparation for fine sectioning. More probably, the difference between Hydrogenomonas and our organism rests with a non-polymer electron-dense matrix that persisted in the electron micrographs of rhizobium. Indications of the stainability of areas from which the polymer was removed by chloroform extraction support the indication that in rhizobium the polymer was closely associated with the cytoplasm (possibly the small granules noted in this paper) and did not simply displace it.

The work reported in this paper was supported by the Commonwealth Reserve Bank (Rural Credits Division), Wheat Industry Research Funds, and the Research Committee, University of Sydney. 



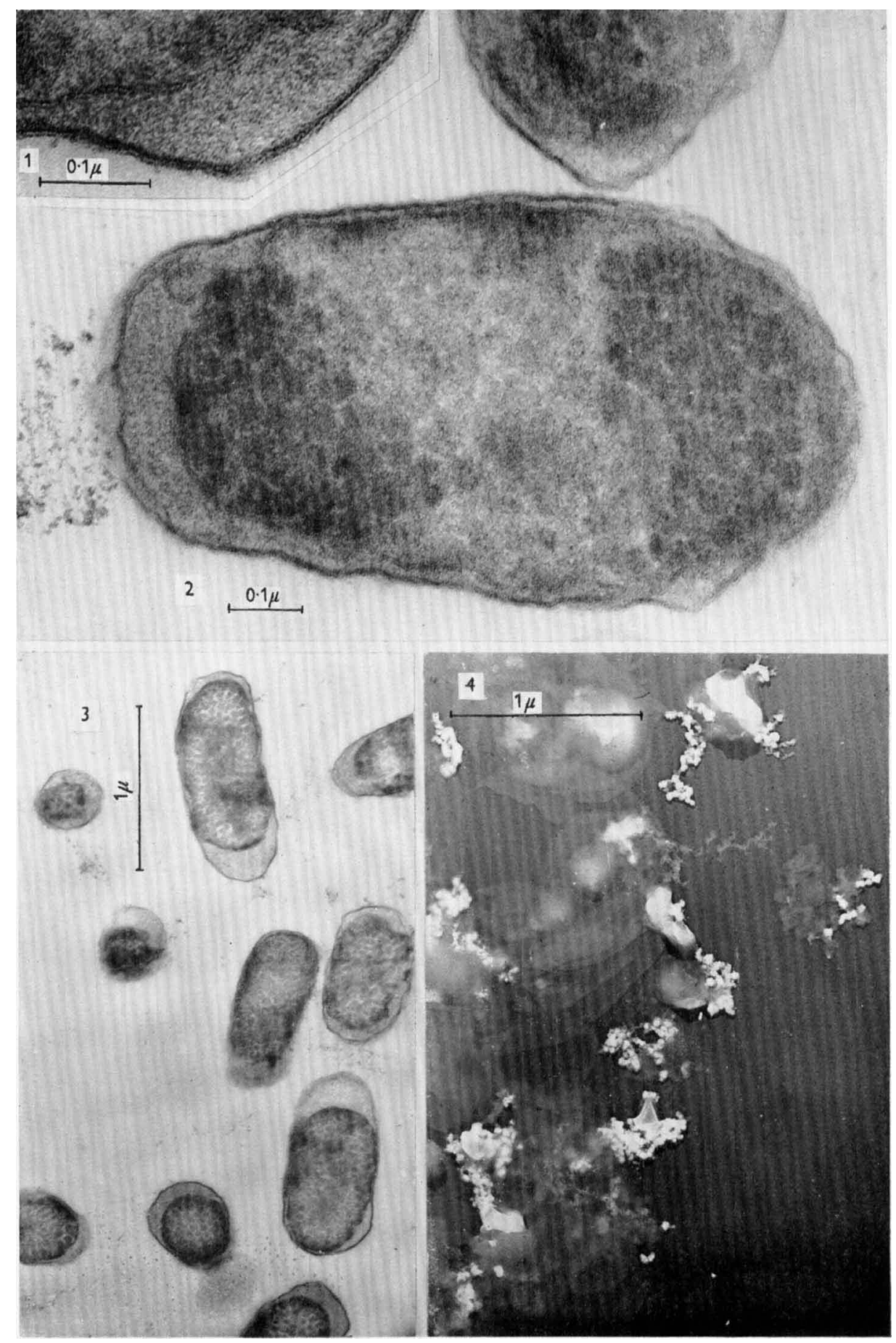




\section{REFERENCES}

BeEr, M. (1960). Disposition of membranes in Alcaligenes faecalis. J. Bact. 80, 659.

Burdon, K. L. (1946). Fatty material in bacteria and fungi revealed by staining dried fixed slide preparations. J. Bact. 52, 665.

Doudoroff, M. \& Stanier, R. Y. (1959). The role of poly- $\beta$-hydroxybutyric acid in the assimilation of organic carbon by bacteria. Nature, Lond. 183, 1440.

Duncan, R. E. B. \& Porteus, J. W. (1953). The identification and determination of the lower straight chain fatty acids by paper partition chromatography. Analyst, 78, 641.

Forsyth, W. C. G., Hayward, A. C., \& Roberts, J. B. (1958). Occurrence of poly- $\beta$ hydroxybutyric acid in aerobic Gram-negative bacteria. Nature, Lond. 182, 800.

Humphrey, B. A. \& Vincent, J. M. (1962). Calcium in the cell walls of Rhizobium trifolii. J. gen. Microbiol. 29, 557 .

Kellenberger, E. \& RYter, A. (1958). The cell wall and cytoplasmic membrane of Escherichia coli. J. biophys. biochem. Cytol. 4, 323.

Képìs, A. \& Peaud-Lenoel, C. (1952). Sur les propriétés et la constitution des lipides $\beta$-hydroxy-butyriques. C.R. Acad. Sci., Paris, 234, 756.

Lemorgne, M. (1925). Étude sur l'autolyse microbienne; acidification par formation d'acide $\beta$-hydroxy-butyrique. Ann. Inst. Pasteur, 39, 144.

Lemoigne, M. (1946). Fermentation $\beta$-hydroxy-butyrique. Helv. chim. Acta, 29, 1303.

Lemoigne, M., Sanchez, G. \& Girard, H. (1943). Sur la characterization de la fermentation $\beta$-hydroxy-butyrique. Ann. Inst. Pasteur, 69, 187.

Macrae, R. M. \& Wilkinson, J. F. (1958). Poly $\beta$-hydroxy-butyrate metabolism in washed suspensions of Bacillus cereus and Bacillus megaterium. J. gen. Microbiol. 19, 210.

Merrick, J. M. \& Doudoroff, M. (1961). Enzymatic synthesis of poly $\beta$-OH-butyric acid in bacteria. Nature, Lond. 190, 1215.

North, R. J. (1961). Method of reaching the membrane systems of micro-organisms. Nature, Lond. 190, 1215.

RoBertson, J. D. (1955). The ultra-structure of adult vertebrate peripheral myelinated nerve fibres in relation to myelinogenesis. J. biophys. biochem. Cytol. 1, 271.

Robertson, J. D. (1958). Structural alterations in nerve fibres produced by hypotonic and hypertonic solutions. J. biophys. biochem. Cytol. 4, 349.

Schlegel, H. G., Gottschalk, G. \& von Bartha, R. (1961). Formation and utilization of poly- $\beta$-hydroxy-butyric acid by knallgas bacteria (Hydrogenomonas). Nature, Lond. $191,1463$.

Smithies, W. R., Gibbons, N. E. \& Bayley, S. (1955). The chemical composition of the cell and cell wall of some halophilic bacteria. Canad. J. Microbiol. 1, 605.

VINCENT, J. M. (1962). Requirements of rhizobium for calcium and magnesium. J. gen. Microbiol. (in the Press).

Williamson, D. H. \& Wilkinson, J. F. (1958). Isolation and estimation of the poly- $\beta$ OH-butyrate inclusions in Bacillus species. J. gen. Microbiol. 19, 198.

\section{EXPLANATION OF PLATE 1}

Fig. 1. Rhizobium trifolii section: details of cell wall and cytoplasmic membrane.

Fig. 2. $R$. trifolii section: cell wall, cytoplasmic membranes and granules in cytoplasm.

Fig. 3. R. trifolii section: Inter-membrane areas; granules in cytoplasm.

Fig. 4. R. trifolii: Disintegrated cells to show granules and residual walls. 